УДК 75(477).071(092)

DOI https://doi.org/10.24919/2308-4863/34-4-2

\author{
Роман ПЕТРУК, \\ orcid.org/0000-0001-6221-7916 \\ заслужений діяч мистецтв Украӥни, \\ доиент кафедри монументально-декоративного і сакрального мистеитва \\ Київської державної академії декоративно-прикладного \\ мистеитва і дизайну імені Михайла Бойчука \\ (Київ, Україна) artromanpetruk@gmail.com
}

\title{
ТВОРЧА Й ПЕДАГОГІЧНА ІПОСТАСІ ПРОФЕСОРА В. І. БАРИНОВОЇ-КУЛЕБИ
}

У статті йдеться про становлення творчої особистості однієї з найяскравіших сучасних українських мисткинь, академіка НАМ України, народного художника України, професорки кафедри живопису і композиції Національної академії образотворчого мистецтва і архітектури (НАОМА) Віри Іванівни Баринової-Кулеби.

Натепер актуальним є дослідження ї̈ авторської методики для викладання живопису $і$ композиції студентам першого курсу відділення живопису факультету образотворчого мистеитва НАОМА.

У дослідженні нами узагальнено досвід, отриманий В. Бариновою-Кулебою під час навчання в провідних українських мистиів, який трунтується на системі потужної бази, наробленої поколіннями педагогів Украӥнської академії мистеитва (1917) (нині - НАОМА). Дані досягнення відіграють важливу роль у формуванні й функціонуванні сучасної сфери науково-педагогічної діяльності та мистецької освіти. Доречним буде зауваження, що автор статті також навчався в иієї професорки. Особлива увага в дослідженні закиентована на педагогічному аспекті організації нею навчального процесу, базовою моделлю якого є поетапний алгоритм ведення практичних завдань та їхній аналіз на основі виконаного. Відповідальною місією педагога є формування не тільки загального вектора розвитку курсу, а й індивідуального підходу до розкриття потенціалу кожного студента.

У статті почергово розглянуто передумови та певний суспільний контекст формування особистості педагога-методиста, професора В. І. Баринової-Кулеби: дитинство, період навчання в Харківському художньому училищі, Київскому державному художньому інституті. Простежено тематичний спектр циклів творів, індивідуальні особливості образної мови, виявлено концепцію авторського феномена «Автопортрета з уяви», де мисткиня є не тільки автором, а й героєм свойх картин.

Матеріал даної статті, присвячений аналізу творчої та педагогічної іпостасей видатної мисткині й педагога В. Баринової-Кулеби, є важливим для розуміння специифіки викладання фахових дисциплін на кафедрі живопису і композииї НАОМА, а також суттєвим для розуміння історії та особливостей мистецької освіти в другій половині $X X-$ початку XXI cm.

Ключові слова: методика викладання фахових дисциилін, образотворення, академічний живопис, творчість, композиція, Віра Баринова-Кулеба, НАОМА.

\begin{abstract}
Roman PETRUK,
orcid.org/0000-0001-6221-7916

Honoured Art Worker of Ukraine,

Associate Professor at the Department of the Monumental-Decorative and Sacral Arts

Mykhailo Boichuk Kyiv State Academy of Decorative Applied Arts and Design

(Kyiv, Ukraine) artromanpetruk@gmail.com
\end{abstract}

\section{CREATIVE AND PEDAGOGICAL IMAGE OF THE PROFESSOR V. I. BARYNOVA-KULEBA}

The article describes the development of the artistic personality of Vira Ivanivna Barynova-Kuleba, who is one of the most prominent modern Ukrainian artists, the academician of the National Academy of Arts of Ukraine, People's Artist of Ukraine and the professor in the Department of Painting and Composition within the National Academy of Fine Arts and Architecture (NAFAA).

The research of her original teaching technique of the visual arts and composition for the first-year students at the Painting Department in the NAFAA Fine Arts Faculty is topical currently.

The research generalizes the experience of $V$. Barynova-Kuleba during her education under the most prominent Ukrainian artists. The basis for this experience is the massive base system, created by the generations of the pedagogues from the National Academy of the Fine Arts (1917) (currently NAFAA). These achievements are crucial for the formation and function of the modern area of the scientific and pedagogical activity and artistic education. Worth mentioning is the fact that the author of the article has studied under the above-mentioned professor. The study focuses on the pedagogic aspect of the educational procedure organization by the professor. The prototype for the procedure is a stage-based 
algorithm of the practical tasks implementation and analysis, based on the completed assignments. The pedagogical crucial aim is not only the formation of the general course direction, but also the individual approach to each student's potential discovery.

The article alternately reviews the prerequisites and a certain social context of the individual formation of the pedagogue-methodologist, Professor V. I. Barynova-Kuleba: her childhood, the study in the Kharkiv Art College and in Kyiv State Art Institute. It follows the thematic range of the series of works, displays the original concept of the selfportrait from imagination, in which the artist is not only the author, but also the subject of her paintings. The article also highlights the individual aspects of the graphic communication.

The article dedicates the contents to the analysis of the creative and pedagogic images of the artist and pedagogue $V$. Barynova-Kuleba. The subject matter is crucial to understand the peculiarities of the teaching professional subjects at the NAFAA Department of Painting and Composition. It is also essential for understanding the history and peculiarities of the art education during the second half and the beginning of the XX-XXI centuries.

Key words: professional subjects teaching techniques, image creation, academic fine arts, creative work, composition, Vira Barynova-Kuleba, NAFAA.

Постановка проблеми. Віра Іванівна Баринова-Кулеба (1938) - визначна українська мисткиня другої половини XX - початку XXI ст., живописець, педагог, що виховала не одне покоління українських мистців, які формують позитивний імідж національної культури як в Україні, так і поза іiї межами. Народний художник України, дійсний член (академік) НАМ України, професорка В. І. Баринова-Кулеба всесвітньовідома творами, що відображають історію України, історію художника, котрий проносить через життя любов до природи, звичаїв і традицій українського народу. У центрі її світовідчуття - людина.

У мистецькій освіті XXI ст. доцільним $є$ дослідження й узагальнення творчих досягнень попередніх поколінь. Ключовою особистістю, що вплинула на формування сучасного мистецького середовища, є Віра Іванівна Баринова-Кулеба. У творчості та педагогічній роботі мисткиня, котра понад півстоліття працює зі студентами, звертається до кращих надбань українського та світового мистецтва, $є$ носієм школи образотворення, що зародилась у стінах нинішньої НАОМА. Висвітлення ролі особистості В. Баринової-Кулеби у збереженні школи $є$ важливим для розуміння пріоритетів розвитку мистецької освіти України.

Аналіз досліджень. Саме творчості В. Баринової-Кулеби присвячено публікації в арт-каталогах, журналах, фахових та періодичних виданнях. Переважно це рефлексії від українських діячів культури та митців, що висвітлюють творчий шлях і біографію Віри Іванівни (Бараневич, 2008: 397-401; Давиденко, 2008: 12-13; Поліщук, 2017: 46-48). Вагомою джерельною базою $\epsilon$ автобіографічні нариси мисткині, занотовані нею спогади, а саме: «Автопортрет з уяви» (БариноваКулеба, 2013: 190-192), «На хуторі залишились садки 3 хрестами» (Баринова-Кулеба, 2008: 67), «Спогади про... майбутнє» (Кулеба-Баринова, 2012: 72), «Рефлексії душі» (Баринова-Кулеба, 2006: 47-51), «Так думається мені» (Баринова-
Кулеба, 2008: 120-121). Проте найбільш важливими джерелами нашого дослідження слід вважати бесіди автора статті 3 В. БариновоюКулебою, а також досвід, здобутий під час його навчання у професорки і творчої співпраці 3 нею впродовж 12-ти років.

Мета статті. У працях про В. БариновуКулебу здебільшого йдеться про творчу позицію мисткині, світоглядно-філософські та фольклорні мотиви ii творчості, тому метою цієї статті $\epsilon$ висвітлення педагогіко-творчої іпостасі таланту очима ії учня, колишнього студента й асистента.

Виклад основного матеріалу. Творчий доробок В. Баринової-Кулеби налічує десятки циклів, різних за манерою візуалізації та стилізації образів. Це і реалістично-академічні твори - масштабні полотна (здебільшого раннього чи, так би мовити, радянського періоду) і умовно-декоративні картини-притчі. Високій фаховій підготовці, здобутій у Харківському художньому училищі, а згодом у Київському державному художньому інституті, творчих майстернях Академії мистецтв СРСР, на стажуванні в Берліні, передувало пізнання мистецтва, взяте від батьків, котрим присвячено низку творів. Ще в дитинстві, у рідному селі Римарівка, що на Полтавщині, маленька Віра почала малювати крейдою на печі між коминками, уважно всотуючи настанови мами: «Віро, малюй радість! - А що таке радість, мамо? - Радість - то діти і квіти» (Баринова-Кулеба, [200-]). Та на долю випала не лише радість, а й голодомори, війни, революції, колгоспи... «Мовчазний крик матерів, виття собак, рев худоби, злість чоловіків, переляк дітей - усе це подумки повертає до пережитого. Малюю. Малюю все, що в'їлося мені в душу із землі, із зернини, з голубого дихання дитини», каже Віра Іванівна (Баринова-Кулеба, 2011: 2).

Безперервна творча робота, зацікавленість у пізнанні мистецтва, залюбленість у світ і вимогливість до себе сформували особистість видатного педагога-методиста професора В. Барино- 
вої-Кулеби. Вона марить студентами, любить їх тільки мріє, як би передати побільше того, чого навчили іiі вчителі, серед яких: А. Константинопольський, в якого Віра Іванівна навчалася в Харківському художньому училищі, де, за розповідями мисткині, робили сотні начерків на день, щоб «поставити» око й руку, десятки етюдів; В. Пузирков, під його керівництвом художниця захищала дипломну роботу «Дівчата» (1965) (іл. 1), ескізи до якої почала робити ще на першому курсі навчання в інституті, і які донині зберігаються у фондах НАОМА; В. Забашта, який шанував ii українську душу; К. Трохименко, під керівництвом якого пізнавала таїнства пленерного живопису; В. Костецький - неодноразовий керівник літньої практики разом із А. Пламеницьким; М. Стороженко, котрий викладав рисунок на другому курсі під час навчання.

Кожен художник народжується 3 контексту, в якому він формується, - як від взаємодії з педагогами, так і з одногрупниками. I в цьому Вірі Іванівні пощастило. На одному курсі з нею навчалися В. Бєлік, М. Вайнштейн, О. Волненко, В. Гурін, М. Козлов, Н. Марченко, творчий доробок яких вагомо збагатив українську мистецьку скарбницю. Кожен із них був носієм уже великої школи. Так, В. Гурін - випускник Кримського художнього училища, учень відомого, але недооціненого в той час художника й теоретика мистецтва М. Писанка, автора посібника «Рух, простір і час в образотворчому мистецтві», М. Вайнштейн - випускник Київської художньої середньої школи ім. Т. Г. Шевченка, згодом відомий як один із класиків українського андеграундного мистецтва 1960-70 х років.
Упродовж навчання кожен викристалізувався в неповторну творчу особистість зі своїм стилем, світосприйняттям, філософією. Твори Віри Іванівни студентських років вирізняються декоративністю, лаконізмом і гострою пластикою композиції, витонченим і водночас могутнім живописом, віртуозним рисунком. Кожен іiі етюд - влучне попадання в колір, образ, тон. Чи то «Напівоголений натурник» (1960) (іл. 2), чи «Сестра Валя» (1960), що є прикладом етюду голови на пленері, ескіз картини чи натюрморт - у всьому відчутне глибинне розуміння гармонії, простору, площини.

Навчання в Академії починається зі знайомства, коли в одній академічній майстерні збираються першокурсники з різних куточків України. Організувати роботу - це непроста й відповідальна місія педагога. Віра Іванівна обов' язково занотовувала, хто звідки, хто після училища і має сильнішу підготовку, а хто прийшов одразу після школи. Все це для того, щоби сформувати певний образ курсу, вектор його розвитку, вибудувати етичні стосунки і відчути готовність до розвитку в закладі. Тоді коли педагоги $з$ рисунка ставлять постановки 3 гіпсовими головами, Віра Іванівна всіх веде спочатку на пленер, щоб відчути темперамент кожного студента, здатність до композиційного мислення. Композиція, пластичне мислення і любов до малювання для викладача головне: «Композиція - це фантазія, без фантазії немає художника» (Розмова, [2010]: 1). Адже академічне навчання на живописному факультеті підпорядковане навчальній програмі 3 живопису, рисунка, композиції. А для справжнього педагога надзавданням є розкриття потенціалу кожного студента. «Найголо-

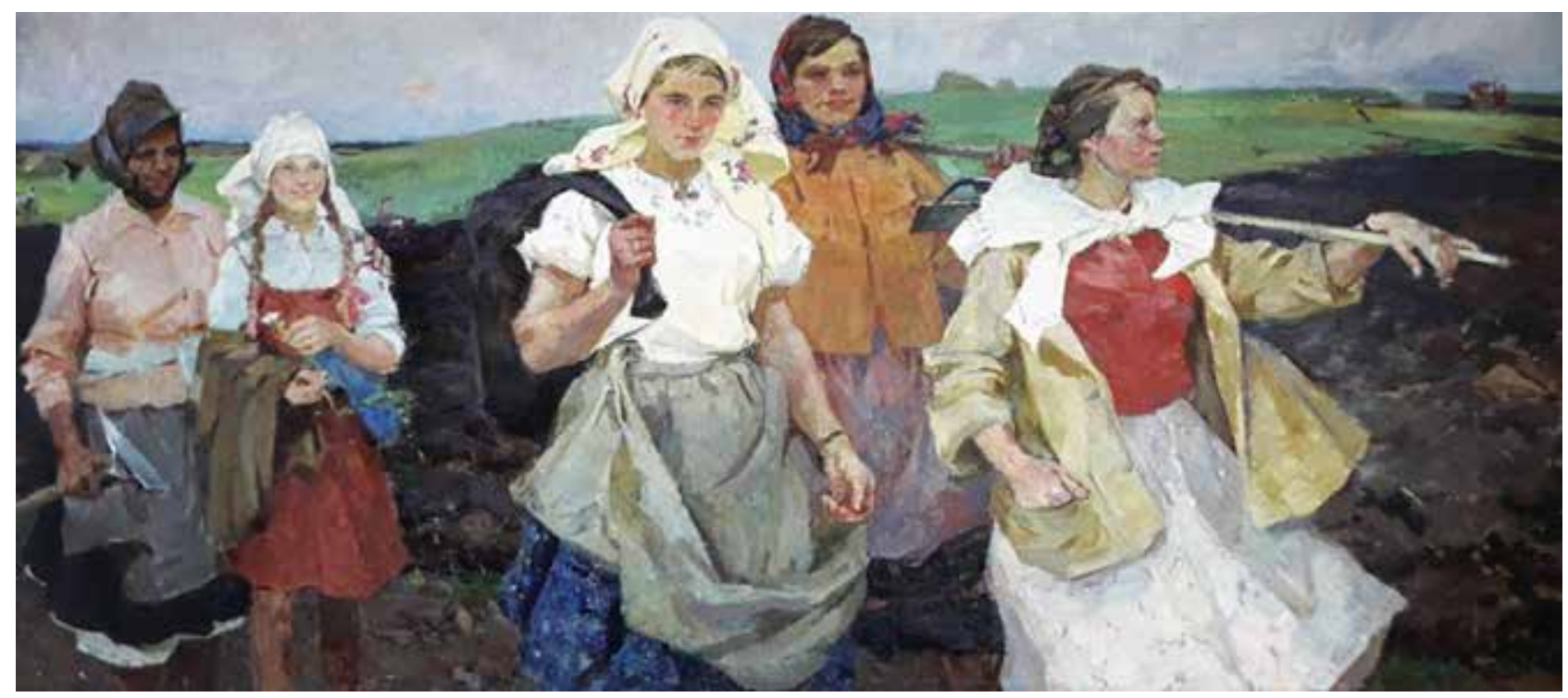

Іл. 1. В. Баринова-Кулеба. Дівчата. Полотно, олія. 130х300. Дипломна робота. Керівник - В. Пузирков. 1965 р. 
внішим у процесі навчання $є$ звернення до живої натури та вивчення традицій академічної школи й українського мистецтва», - вважає професорка (Національна академія образотворчого...).

На пленері педагог вводить студентів у систему мислення формою, навчає в жодному разі не змальовувати фотографічно, а відчути, полюбити, дивитись не тільки на об'єкт зображення, а й довкруж. Ділиться спогадами про своє навчання, коли на літній практиці в Каневі, закомпонувавши панорамний пейзаж, відчула за спиною педагога, іiï тодішнього керівника практики I. Штільмана: «Ніколи не дивіться буквально, шукайте образ, структуру композиції. А може, Вам для пластичного поєднання картини знадобиться та хмарина, що за спиною» (Розмова, [2010]: 3). Добре запам'ятавши цю пораду, Віра Іванівна й досі використовує принцип, коли перед написанням пейзажу досліджується з пензлем в руках і олівцем місцевість, виконується ряд етюдів, елементи яких можна згодом використати в картині. Такий методологічний підхід близький до системи Віктора Зарецького (Медведєва, 2006: 285), коли перед початком роботи на форматі треба написати хоча би п'ять двадцятихвилинних етюдів-пошуків на стан, ритм, пропорцію, розкласти конфігуративно на абстрактні плями, виконати так звані фор-ескізи. Тут відбувається динамічне й почуттєво-емоційне піднесення і пошук самого формату (вертикаль, горизонталь, квадрат). Згадуючи досвід профеcopa В. Гуріна, одногрупника Віри Іванівни, що навчався азів образотворення у Миколи Писанка, мотив природи, з якого пишеться етюд, порівнювали $з$ музикою Гріга, Баха, малювали музику, що сприяло поетичному сприйняттю дійсності, розумінню синтезу мистецтв.

У майстерні ж ставиться багатогодинна постановка. Все навчання в Академії побудоване на пізнанні людського тіла, його архітектоніки, пластики. На першому курсі вивчають будову голови людини, поступово завдання ускладнюють: портрет з кистю руки, портрет з руками. На наступних курсах поступово переходять до оголеної натури, досліджуючи найскладніші ракурси. «Тіло людини - храм Духу Святого», - написано в Біблії. Тому дуже важливим $\epsilon$ процес заглиблення в психологію людини, пізнання жесту, погляду, руху, ритму. У процесі виконання завдання 3 написання голови на першому курсі Віра Іванівна спонукає не просто до красивого живопису, а до образотворення, «щоб було видно, про що думає натурник» (Розмова, [2010]: 2), як і ії̈ навчали вчителі, зокрема I. Н. Штільман ще на першому курсі.

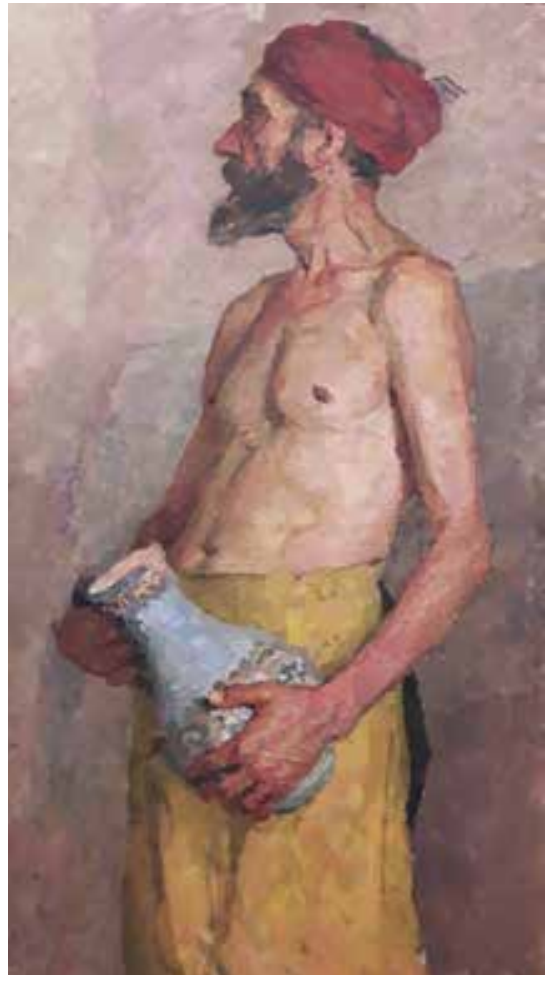

Іл. 2. В. Баринова-Кулеба. Напівоголений натурник. Полотно, олія. Керівники -

К. Трохименко, В. Виродова-Готьс. II курс, 1960 р.

У творчій і педагогічній роботі Віра Іванівна сповідує українські фольклорні мотиви, досконало знає історію українського вбрання, щедро ділиться досвідом зі студентами. Складається враження, що хвилину тому тримала в руках хустку, кілька вправних рухів - і в натурниці світиться лице - то вже образ матері, вправно підібране тло, й обличчя випромінює зовсім нову енергію, в іншому кінці майстерні натурник у білому на білому - так твориться гама, в центрі поставлено завдання для студентів на пряме освітлення - такі любив і Федір Кричевський, що є одним із засновників Української академії мистецтва (1917). Під керівництвом професорки студенти намагаються віднайти індивідуальні пластичні вирішення, а майстерня стає тією творчою лабораторією, де 3 маси різних драперій виникають образи і проглядаються рухи Віри Іванівни. А ще до кожного образу вона має історію: «Так носили хустку матері, а так - тільки на Полтавщині, а молоді дівчата тільки так, а жінка в тяжі - так < ..> Багата скарбниця нашої культури!» (Розмова, [2010]: 2). У такий спосіб прищеплюється любов і жага до пізнання народних традицій.

Відомо, що живопис починається 3 палітри. Спочатку Віра Іванівна навчає, як правильно стати, в якій площині має бути палітра. Часто недосвідчений художник, компонуючи щось 
біля вікна, а потім приміряючи роботу на стіні, не розуміє, чому вона така темна. Тому важливо правильно підготуватись до роботи. «Палітра має відповідати площині формату та знаходитись у вертикальному положенні. Біле й чорне тон - по центру один від одного, серце людини зліва, а від нього йде тепло, тому теплі відтінки справа, холодні ж - зліва (так побудована людина, що права півкуля головного мозку відповідає за ліву частину тіла, а ліва - навпаки). Починаємо 3 фор-ескізу на маленькому форматі. На даному етапі важливо правильно розподілити тональні й колірні співвідношення, відчути силует, а вже потім працювати над психологією» (Розмова, [2010]: 2).

Необхідно зауважити, що особливої уваги заслуговує момент компонування на полотні, яке починаємо тільки після пошукових ескізів, картону, виконаного в м'якому матеріалі (вуглина, coyc). Лише так студент пізнає культуру тонального рисунка, адже специфіка роботи живописця вимагає розуміння тону. Важливим також є окреслення пропорції, оскільки необхідно схопити рух, але в жодному разі не змальовувати. Віра Іванівна навчає дивитися на стопи, відчути хребет, конструкцію моделі навіть тоді, коли пишеш портрет.

Нi для кого не $\epsilon$ секретом, що твори мистецтва вражають, діють, надихають, але завдяки методиці В. Баринової-Кулеби студенти отримують ключ до пізнання - це окрилює. Тільки висока фахова підготовка, розуміння й тієї системи, що віками напрацьовувалась кращими умами, формують справжнього художника, вільного, незакомплексованого. Часто майстриня розповідає про одну з улюблених іiі художниць - Катерину Білокур, яка є прикладом самовідданості й жаги.

Щодо Віри Іванівни-студентки, то навчалась вона лише на відмінно й одразу після закінчення першого курсу (1960) стала ленінською стипендіаткою на всі роки навчання. Завжди із вдячністю відгукується Віра Іванівна про молоду тоді іiі вчительку, а нині поважну професорку і колегу В. Виродову-Готьє. Досі пам'ятає враження від дипломної картини Валентини Гаврилівни «Дівчата-колгоспниці» (1959). Сама В. Виродова-Готьє навчалася у видатного майстра О. Шовкуненка, багато копіювала Кричевського, досліджувала манеру його письма. Так формувалася школа - осягненням доробку вчителів, правчителів, розумінням витоків, повагою до традицій. Копіювання творів класичного мистецтва - невід'ємна складова частина навчального процесу. Віра Іванівна навчає сприймати класику як натуру, вчитись у великих майстрів, аналізу- вати систему їхнього мислення, розуміння тону й кольору, де підкреслити, а де списати, надихає на осягнення мистецької грамоти, так званої конституції живопису, напрацьованої віками. Прикладом може бути репродукція Веласкеса або ж живописні твори М. Стороженка, В. Гуріна чи Т. Голембієвської, що зберігаються на кафедрі живопису і композиції НАОМА. 3 особливим трепетом Віра Іванівна згадує Т. Яблонську, яка своїм талантом й емоційним темпераментом впливала на багатьох художників. Навчальні постановки Тетяни Нилівни Віра Іванівна постійно ставить за приклад студентам, розповідає про школу Ф. Кричевського та М. Бойчука, оскільки сама $\epsilon$ носієм традицій великої школи, провідником ідей високого мистецтва. Це виховує смак, культуру сприйняття і повагу до минувшини, розуміння сучасного. Часто наставниця цитує М. Глущенка: «Ніколи не пишіть те, що бачите, а те, що відчуваєте» (Давиденко, 2008: 12-13).

Доречно також сказати про прагнення Віри Іванівни навчити студентів любити свою душу, «бо тільки людина, яка любить свою душу, може любити іншого і все живе» (Розмова, [2010]: 1). Тому ій завжди цікаво побачити їхні автопортрети. Хтось реалістично, по-учнівськи виліпить обличчя, а хтось проявить фантазію, як-от відомий нині світлої пам'яті О. Голосій, що під час навчання намалював себе у клітці в образі дитини. Буває, що виникають розбіжності серед професорсько-викладацького складу кафедри щодо того, як сьогодні навчати студентів, однак Віра Іванівна всіляко підтримує творче начало і нестандартне мислення в композиції, експерименти. У творчому доробку майстрині часто зустрічаються автопортрети в різних образах, які мають і певне символічне значення. Скажімо, відомий «Автопортрет у квітчастій хустці» (1998) (іл. 3) став подарунком самій собі до дня народження.

На ньому художниця 3 пензлем у руці, здається, дивиться прямо в душу. Тло літописне, стилізовано проглядаються незабуті й незабутні предки, що постають ніби із землі. Земля дихає, а навколо голови прямокутною формою позначено місце кожного в ній. Натхненно, як на іконі рушник, зав'язана на голові хустка 3 водоспадами квітів. Здається, от-от - і почне малювати, а може, й заговорить. Але ні, ії картини промовляють краще за слова. У них душа України.

Феноменом Віри Іванівни $\epsilon$ «Автопортрет 3 уяви», який, за іiї словами: «Малюю. I те малювання - чи то з голови, чи то з дихання - не знаю. Інколи, як у спеку, хочеться джерельної води, так і я спрагло хапаюся за пензель, за фарби. Пор- 
трети з уяви стукають у серце, їм уже час у життя. Не відчуваю часу, світу і себе в ньому. Творчість втягує, і я розчиняюся в ній. Щасливі миттєвості. Як доторк маминих рук, як пестощі маленької дитини» (Баринова-Кулеба, 2011: 2). Цікавим $є$ спостереження, як Віра Іванівна малює себе чи не в кожній роботі: то вона маленька дівчинка чи дитина в колисці, а десь уже доросла Bipa, до речі, так вона підписує свої твори, а на іншому полотні - то вже мама 3 дітьми. Вона $€$ не тільки автором, а й героєм своїх картин. На полотні «Чуєш звуки» (2000) - Віра маленька в полі біля мами, на картині «А мені сниться» (1985) - чекає батька, вольовою художницею-матір'ю постає на «Автопортреті з дітьми» (1973), а на «Автопор- треті $з$ гусьми» (2009) (іл. 4) сама, як птах між ними, де малююча рука, ототожнена 3 гусячою шиєю, тягнеться до малювання, як у картині Ван Гога «Їдці картоплі» (1885), де самі їдці схожі на картоплю. Кожна лінія мисткині - то автопортрет.

На картині «Наша корівка Зорька» (1990) стоїть маленькою дівчинкою і п'є тепле молоко біля «великої на весь хлів» корови. Вся правда людини, яка пізнала справжнє єднання 3 природою. Та найцікавішим є те, що манера образотворення мисткині, котра пройшла велику школу, але почула голос власної душі, віднайшла художню мову, унікальну, ні на кого не схожу. Там і декоративна пляма від Гогена, і нерв від Ван Гога, і лінія від Пікассо, й аплікативність від Матісса, й еле-

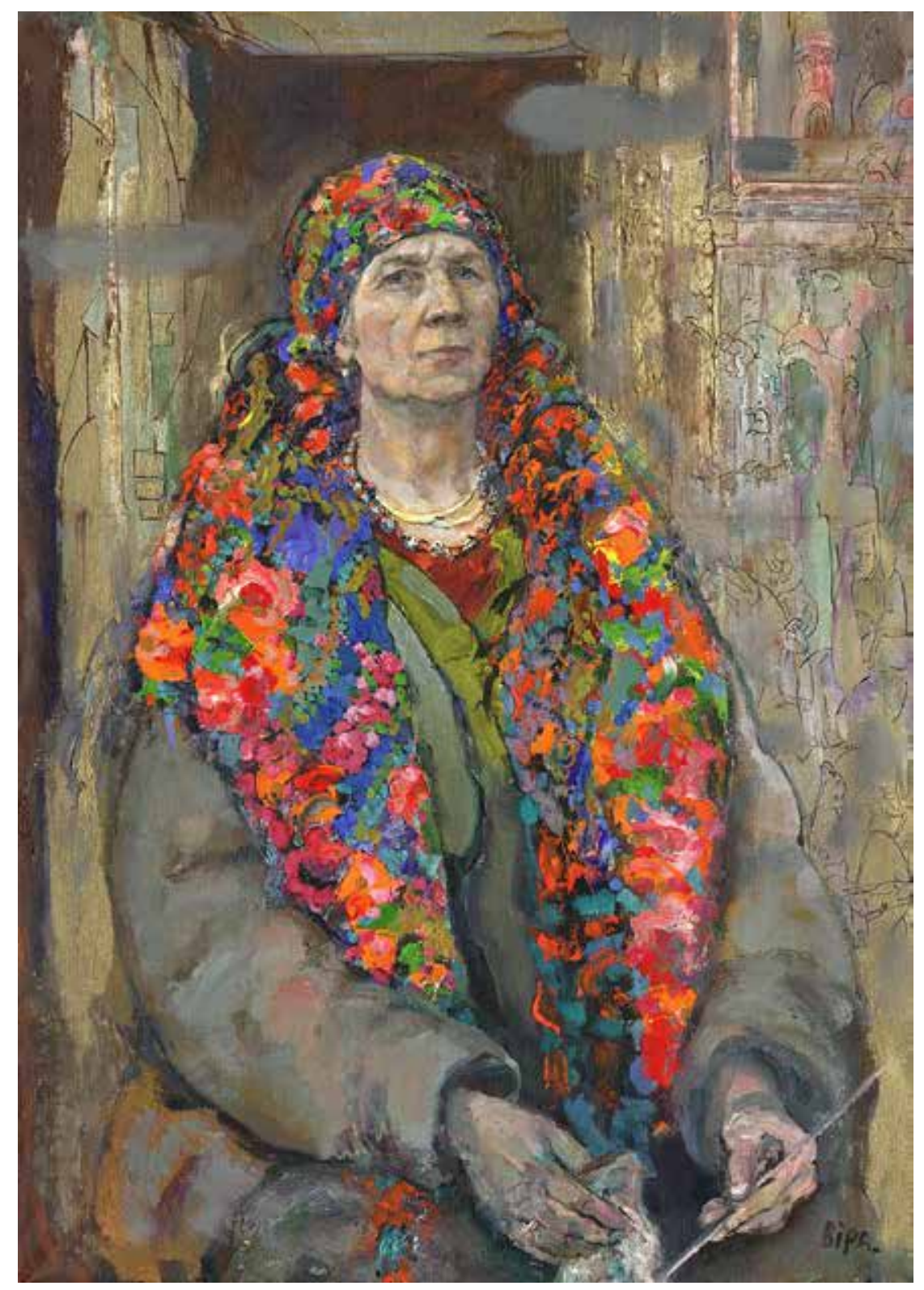

Іл. 3. В. Баринова-Кулеба. Автопортрет у квітчастій хустці. Полотно, олія. 100х70. 1998 р. 


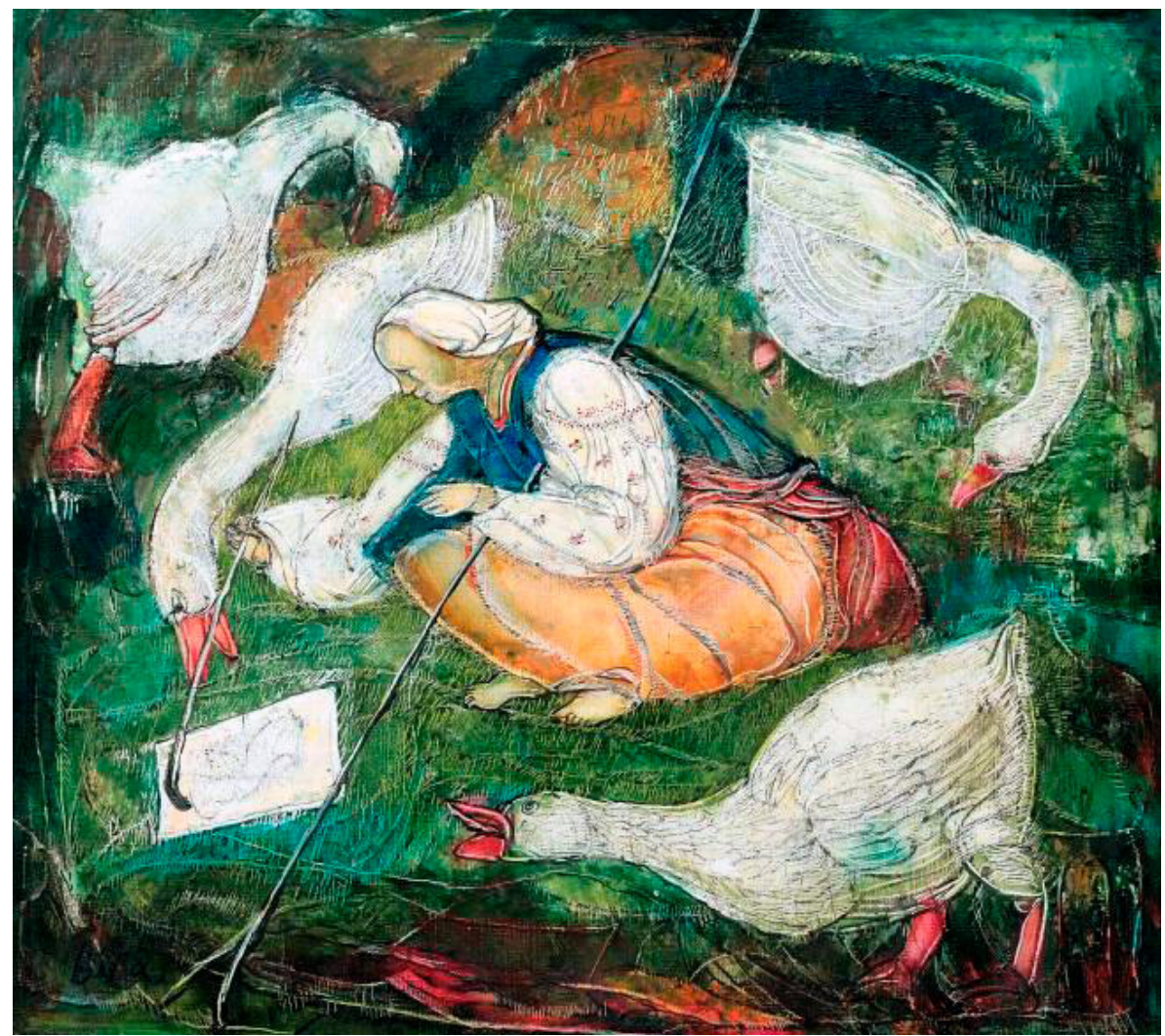

Іл. 4. В. Баринова-Кулеба. Автопортрет $з$ гусьми. Полотно, олія. 60х70. 2009 р.

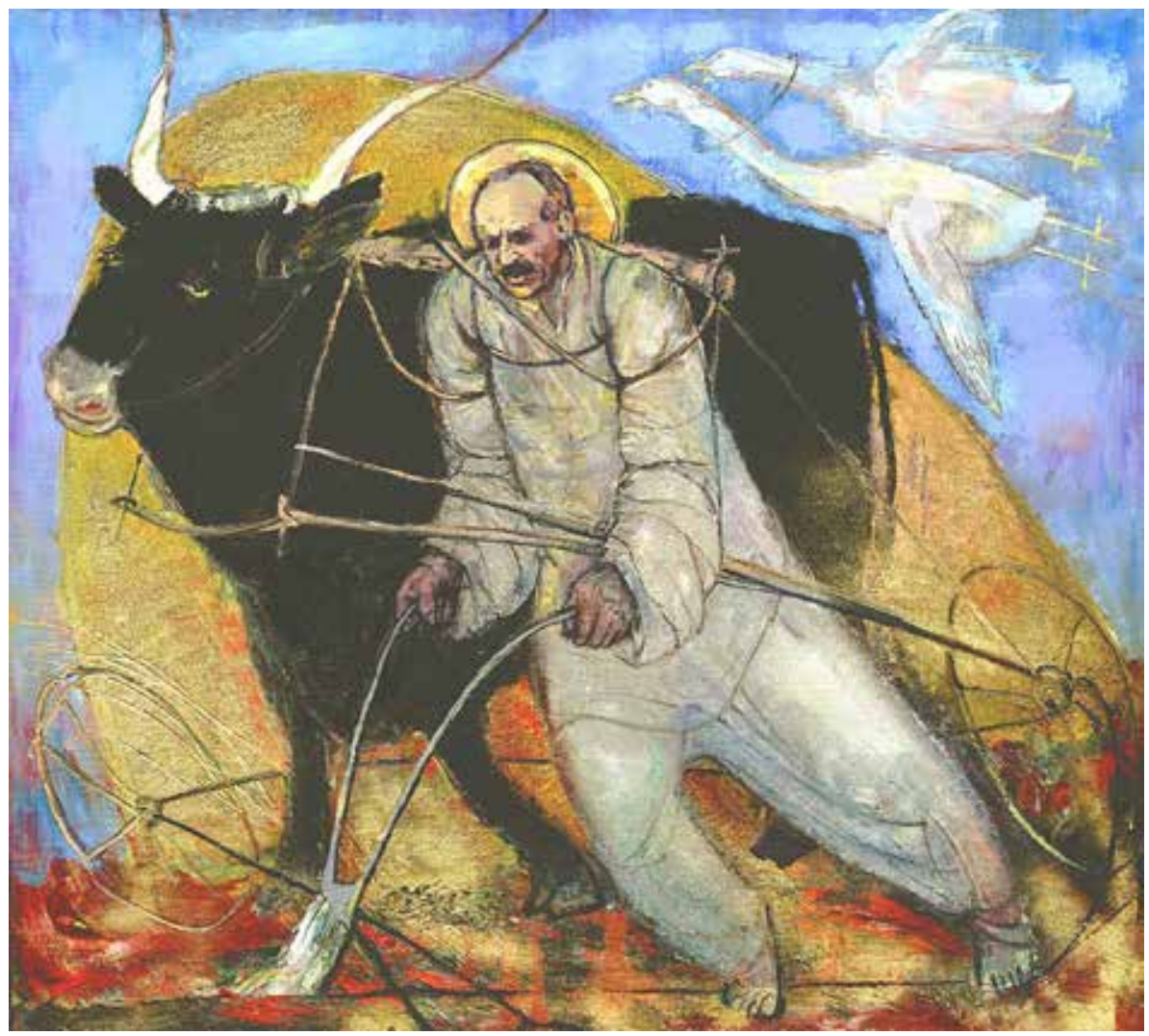

Іл. 5. В. Баринова-Кулеба. Портрет Чорновола. Полотно, олія. 104x125. 1997-2001 pp. 
Петрук Р. Творча й пемагогічна іпостасі професора В. I. Баринової-КулеБи

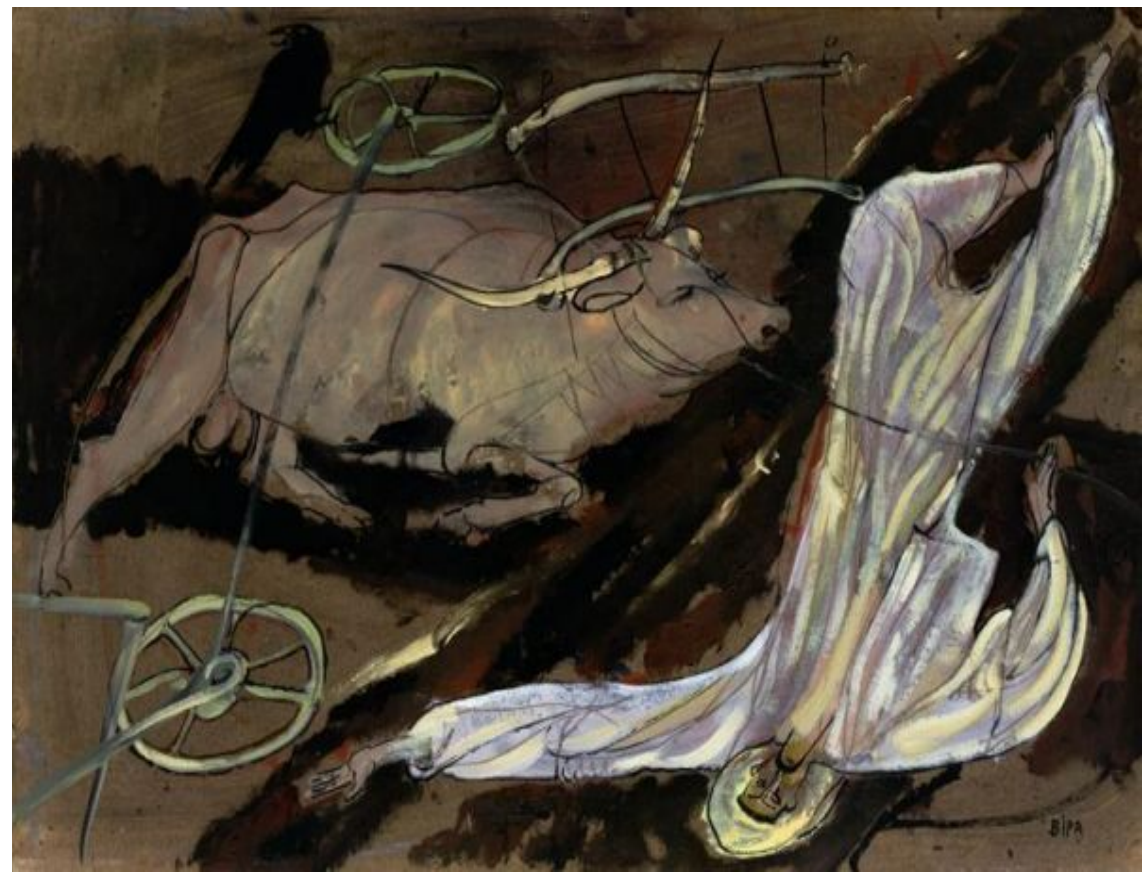

Іл. 6. В. Баринова-Кулеба. Тридцять третій рік. Полотно, олія. 40х60. 1998 р.

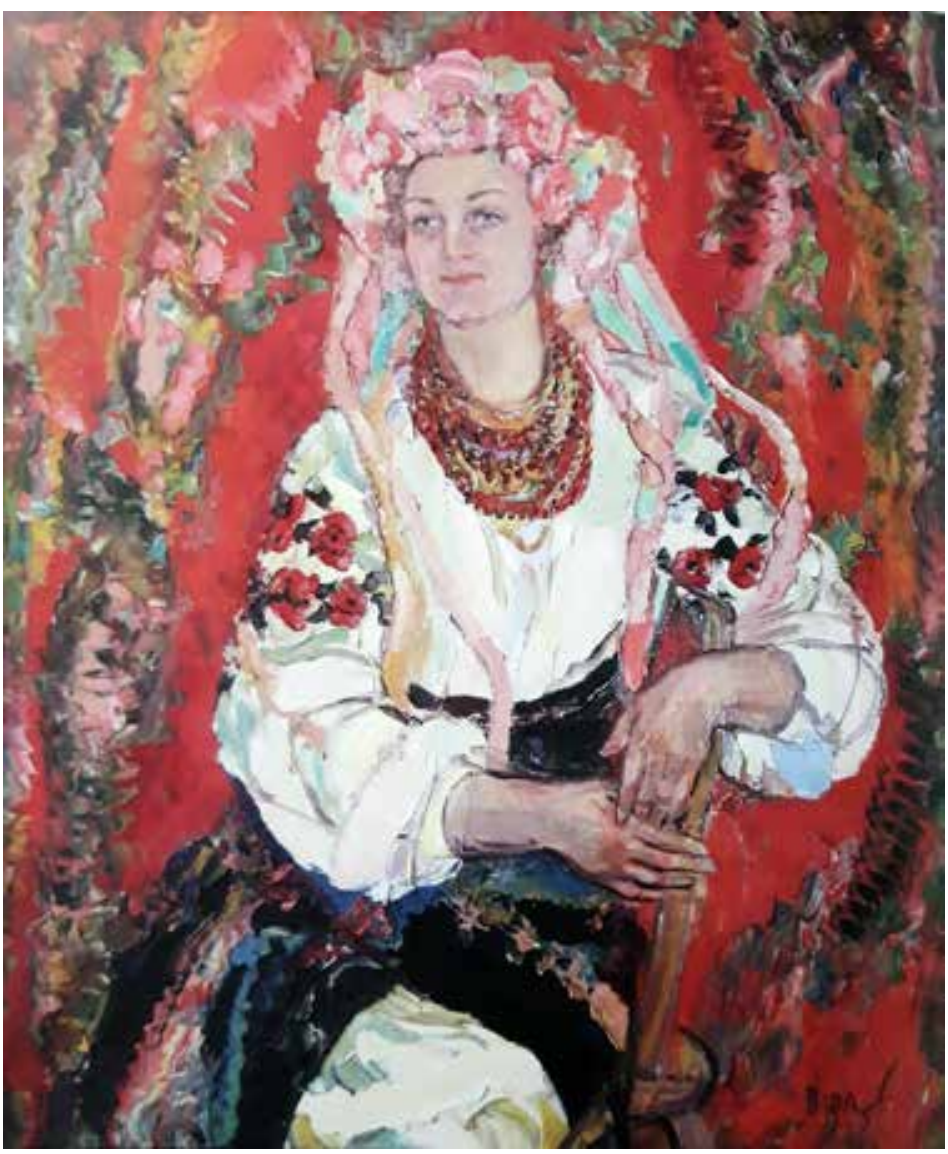

Іл. 7. В. Баринова-Кулеба. Оленочка. Полотно, олія. 104x92. 2000 р. 
менти візантинізму від Бойчука, одухотвореність від Леонардо, світлоносність від Рембрандта, щирість від малої дитини й неповторність самої Віри Баринової-Кулеби.

Варто відзначити, що мисткиня почала викладацьку роботу в КДХІ у майстерні В. Касіяна, де з О. Яблонською викладала живопис і рисунок студентам-графікам. Мабуть, ще тоді в душі художниці відбувся синтез, що згодом вилилось в унікальний iї стиль, де присутня як живописна гармонія, так і графічна елегантність.

Пейзажі чи натюрморти - реалістично-імпресіоністичні, великі картини - класичні, академічні, портрети - з глибоким психологізмом, а от пам'ять, яку вона малює часто, як на пергаменті, - тільки їі.

На формування стилю відчутно вплинула любов Віри Іванівни до декоративно-площинного узагальнення, яке ми часто бачимо в іконі. Образ ікони і вікна в рушникові часто зустрічається на картинах художниці, бо з ікони йде дух вишній, а 3 вікна - промінь світу білого, який так вона любить: «Нічого кращого немає» (2003), «Було, є і буде» (2010), «Щаслива сім’я» (2007-2008). Лише у творах про голодомор чи війну - темрява у вікнах, але обов' язково з проблисками світла, вірою в майбутнє.

Мисткиня досконало знає побут українців і часто використовує елементи інтер'єру та екстер'єру української хати: «Завтра неділя» (1989), «Люлі, люлі...» (2004), «1945 (з мого дитинства)» (1971), звертається до образів видатних діячів культури України. Леся Українка з квітами в руках зображена на картині «У зеленому гаю поблизу Гадяча» (2004), де Леся сидить біля річки на похиленій вербі, форма якої асоціюється з тризубом. Метафоричним $є$ «Портрет Чорновола» (1997-2001) (іл. 5), де він у солом'яному брилі, ніби в німбі, в одному ярмі з чорним волом, який для Віри Іванівни є символом чоловічої сили, космічної енергії, плугом оре землю.

Образ вола - одвічного супутника й помічника селянина, оспіваний у творах художниці, які і про радість, і про народження, i про батька, і про голодомор. Одним із найгостріших і найбільш вдалих творів сучасності, присвячених темі голодомору, $\epsilon$ картина Віри Іванівни «Тридцять третій рік» (1998) (іл. 6), де хрестом на землі лежить чоловік у брилі й у білому вбранні, наче святий, зі своїм волом обидва неживі. Досконало побудована композиція, а глибокий драматизм підсилює колірна гама.

Магістральними у творчості Віри Баринової-Кулеби є такі одвічні теми, як сім'я, родина, любов, батько, мати, дитинство, а особливо багато картин про свята, народні обряди, цикли, присвячені святкуванню Великодня, свята Івана
Купала, жнив, запросин на весілля, танцям. Знаковими $є$ картини про ярмарок у Великих Сорочинцях на Полтавщині - «Купуйте» (2010), «На Сорочинському ярмарку» (2007); напружені й нервово написані картини про «Наймичку» i «Катерину» (2018-2019) Т. Шевченка, де художниця експериментує 3 матеріалом і винаходить авторську техніку письма по негрунтованому льняному полотні, що додає творам ще більшої органічності, синкретизму, показує нерозривний зв'язок із землею. Варті уваги варіації на тему «Не цілуй мене, козаче, бо гуси побачать...»-українське переосмислення Вірою Іванівною «Поцілунку» (1907-1908) Густава Клімта. Картини «Синок мій» (2000), «Стара груша» (1989), «Мій батько у полі» (2010), «Теплий ранок» (2001), «Колючі трави» (2010), «Бабине літо» (1999), «Люблю гусей» (2020) - всі обігріті, облюблені, вихоплені з душі, з пам'яті.

Важливо зауважити, що Віра Іванівна відома своїми творами по всьому світу. Багато працювала в Америці, Китаї, де навчала студентів, даючи уроки живопису. Скажімо, портрет «Оленочка» (2000) (іл. 7) написаний на одному 3 американських майстер-класів.

Всі були вражені дійством, коли художниця писала 3 натури, та ще й портрет. Це було зразком віртуозної майстерності української художниці. Роботи мисткині зберігаються в музеях і приватних колекціях різних країн світу, зокрема у Швейцарії, США, Угорщині, Франції, Великобританії, Німеччині, продавалися на аукціонах Крістіс та Сотбіс. Творча й педагогічна діяльність професорки Віри Баринової-Кулеби високо оцінена державою. Вона - кавалер «Ордена княгині Ольги» III-го ступеня, заслужений діяч мистецтв України, народний художник України.

«Де б я жила, де б малювала, іншою ніколи не стану. Захоплююсь усім прекрасним, воно $\epsilon$ велике і неосяжне. Малюю...», - каже Віра Іванівна (Баринова-Кулеба, 2011: 2).

Висновки. Постать Віри Баринової-Кулеби значне явище в історії українського образотворчого мистецтва другої половини XX - початку XXI ст., a iï вплив як мисткині й педагога на формування мистецької думки, нових поколінь художників і педагогів відіграє непроминальну роль. Методика ведення нею фахових дисциплін підкріплена півстолітнім досвідом викладання на різних факультетах одного з кращих мистецьких навчальних закладів України - НАОМА. Дослідивши життя i творчість художниці, можемо стверджувати про важливість ролі школи у формуванні творчої особистості. 
Матеріали даної статті можуть бути використані істориками мистецтва у створенні монографії про життєвий i творчий шлях видатної мисткині й педагога Віри Баринової-Кулеби, під час дослідницької роботі над вивченням мистецького контексту другої половини XX - початку XXI ст., історії НАОМА, для мистецтвознавчих штудій про методичні й творчі принципи сучасної академічної мистецької освіти.

\section{СПИСОК ВИКОРИСТАНИХ ДЖЕРЕЛ}

1. Бараневич Л. Доля повела їі мистецькими шляхами. (До дня народження В. І. Баринової-Кулеби). Українська академія мистецтва : дослідн. та наук.-метод. пр. Київ, 2008. Вип. 15. С. 397-401.

2. Баринова-Кулеба В. І. А час збігає... : особ. архів В. І. Баринової Кулеби. Б. м.

3. Баринова-Кулеба В. І. Малярство : каталог. Київ, 2011.

4. Баринова-Кулеба В. І. На хуторі залишились садки з хрестами. Віче. 2008. № 21 (234). С. 67.

5. Баринова-Кулеба В. Пам'ять. Українська академія мистецтва : дослідн. та наук.-метод. пр. Київ, 2004. Вип. 11. C. $133-144$.

6. Баринова-Кулеба В. Так думається мені (монолог мисткині). Образотворче мистеитво. 2008. № 1. С. 120-121.

7. Давиденко В. Зберегла колиску. Слово Просвіти. 2008. № 37 (489). С. 12-13.

8. Денисюк О., Поліщук А. Тема материнства у творчості В. І. Баринової-Кулеби. Актуальні питання гуманітарних наук : міжвуз. зб. наук. пр. молодих учених Дрогоб. держ. пед. ун-ту ім. I. Франка. Дрогобич, 2019. Вип. 26. Т. 1. C. $39-47$.

9. Кулеба-Баринова В. Спогади про майбутнє. Віче. 2012. № 15-16. С. 72.

10. Медведєва (Смирна) Л. В. Віктор Зарецький. Митець, рокований добою. Київ : Оранта, 2006. 432 с.

11. Поліщук А. Віра Баринова-Кулеба: сучасність через традиції. Образотворче мистеитво. 2017. № 4. С. 46-48.

12. Поліщук А. Жіночий образ у творчості В. І. Баринової-Кулеби : дипломна робота : рукопис ; НАОМА. Київ, 2017.

13. Розмова Романа Петрука з Вірою Бариновою-Кулебою 14 жовт., 2010 р. : архів автора. 2010. Б. м. С. 1-3.

14. Національна академія образотворчого мистецтва і архітектури. URL: http://naoma.edu.ua/ua/professors/kafedra zhivopisu_kompozits/vravanvna_barnova-kuleba/ (дата звернення: 30.09.2020).

\section{REFERENCES}

1. Baranevych L. Dolia povela yii mystetskymy shliakhamy. (Do dnia narodzhennia V. I. Barynovoi-Kuleby) [Fate led her in artistic ways (Dedicated to the birthday of V. I. Barynova-Kuleba)]. Ukrainska akademiia mystetstva : Doslidnytski ta naukovo-metodychni pratsi - Ukrainian Academy of Arts: Research and methodological work. 2008. 15, 397-401. [in Ukrainian].

2. Barynova-Kuleba V. I. A Chas zbihaye...: [osob. Arkhiv V. I. Barynovoi-Kuleby] [And yet the time goes by...: [personal archive of the V. I. Barynova-Kuleba]]. [B. m.] - No location, 200-. [in Ukrainian].

3. Barynova-Kuleba V. I. Malyarstvo: kataloh [Painting: catalogue]. Kyiv - Kyiv, 2011. [in Ukrainian].

4. Barynova-Kuleba V. I. (2004). «Na khutori zalyshylys sadky z khrestamy» [On the hamlet remained gardens with crosses] Viche - Veche, 21, 67. [in Ukrainian].

5. Barynova-Kuleba V. Pamyat [Memory]. Ukrayinska akademiya mystetstva: doslidn. ta nauk-metod. pr. - Ukrainian Art Academy: research and scientific-methodical works. Kyiv - Kyiv, 2004, 11, 133-144. [in Ukrainian].

6. Barynova-Kuleba V. Tak dumaietsia meni (monoloh mystkyni) [That's what I think] (monologue of the artist). Obrazotvorche mystetstvo - Fine art, 2008, 1, 120-121 [in Ukrainian].

7. Davydenko V. Zberehla kolysku [Kept the cradle]. Slovo prosvity - The word of enlightenment, 37, 2008, 12-13. [in Ukrainian].

8. Denysiuk O. Polischuk A. Tema materynstva u tvorchosti V. I. Barynovoi-Kuleby. [The subject of maternity in the works by V. I. Barynova-Kuleba] Aktualni pytannya humanitarnykh nauk: mizhvuz. zb. nauk. pr. Molodykh vchenykh Drohob derzh. ped. un-tu. im. I. Franka. - Current questions in the humanitarian sciences: inter higher educational establishments' works collection by the younger scientists of the Ivan Franko Drohobych National Pedagogical University. Drohobych Drohobych, 2019, 26, 39-47. [in Ukrainian].

9. Barynova-Kuleba V. Spohady pro... maibutnie [Memories of ... the future]. Viche - Veche, 2012, 16, 72. [in Ukrainian].

10. Medvedyeva (Smyrna) L. V. Viktor Zaretskiy. Mytets, rokovaniy doboyu [Viktor Zaretskiy. An artist, doomed by the era]. Kyiv - Kyiv: Oranta - Oranta, 2006, 432. [in Ukrainian].

11. Polischuk A. Vira Barynova-Kuleba: suchasnist cherez tradytsiy. [Vira Barynova-Kuleba: modern through traditions]. Obrazotvorche mystetstvo - Fine arts. 2017, 4, 46-48. [in Ukrainian].

12. Polischuk A. Zhinochyi obraz u tvorchosti V. I. Barynovoi-Kuleby: dyplomna robota: [rukopys]. [Feminine image in the works of V. I. Barynova-Kuleba: project work [manuscript]]. NAOMA - NAFAA. Kyiv - Kyiv, 2017. [in Ukrainian].

13. Rozmova Romana Petruka z Viroyu Barynovoyu-Kuleboyu 14 zhovt, 2010 r. [An interview by the author with Vira Barynova-Kuleba on October 14. 2010]. [arkhiv avtora] - archive of the author. [B. m.] - No location, 2010, 1-3. [in Ukrainian].

14. Natsionalna akademiya obrazotvorchoho mystetstva i arkhitektury [National Academy of Fine Arts and Architecture] [Elektronnyi resurs] - Digital source. URL: http://naoma.edu.ua/ua/professors/kafedra_zhivopisu_kompozits/vravanvna_ barnova-kuleba/ (visited on 30.09.2020). [in Ukrainian]. 